Jurnal Laut Khatulistiwa, Vol. 5 No. 1 (Febuari, 2021), Hal. 50-55.

ISSN : 2614-6142 (Printed), 2614-8005 (Online)

http://jurnal.untan.ac.id/index.php/lk

JURNAL LAUT

KHATULISTIWA

\title{
Aktivitas Hepatoprotektor Dari Ekstrak Etanol Kerang Ale-Ale (Meretrix sp.)
}

\section{Hepatoprotector Activity From Ale-Ale Ethanol Extract (Meretrix sp.)}

\author{
Bambang Sujatmiko1, Warsidah ${ }^{2 *}$, Dwi Imam Prayitno ${ }^{2}$ \\ 1 Program Studi Ilmu Kelautan, FMIPA Universitas Tanjungpura, Pontianak, Indonesia \\ 2Laboratorium Ilmu Kelautan, FMIPA Universitas Tanjungpura, Pontianak, Indonesia \\ ${ }^{*}$ E-mail : warsidah@fmipa.untan.ac.id
}

Received : 24 Agustus 2021; Accepted: 10 September 2020

Published: 28 February (C) Author(s) 2021. This article is open access

\begin{abstract}
The liver is the largest organ in the body and is the center for metabolism and detoxification of chemical compounds. As the central organ, it turns out that the liver is very susceptible to various diseases such as hepatitis or other diseases. Hepatitis can occur because the body's immune system decreases so that the hepatitis virus can freely infect the liver or the formation of free radicals in the liver, causing inflammation of the liver due to the influence of an unhealthy lifestyle. The concentration of free radicals that are not balanced with antioxidants in the body can cause oxidative stress in the body which can cause cell damage which can lead to degenerative diseases such as liver disease. The damage caused by free radicals in the body can be treated with antioxidants. Based on the results of previous research, it is known that ale-ale shellfish extract has antioxidant activity. The purpose of this study was to determine the chemical components of ale-ale shellfish extract (Meretrix sp.) By conducting phytochemical tests and the hepatoprotective activity of ale-ale shellfish extracts against SGPT and SGOT levels from rabbits induced with CCl4. From this research it is known that the results of phytochemical testing indicate that alkaloid compounds are contained in the ale ale shellfish extract. The hepatoprotection activity of ale-ale shellfish extract (Meretrix sp.) Has the ability to reduce SGPT and SGOT levels from rabbit blood serum that has been induced with $\mathrm{CCl}_{4}$.
\end{abstract}

Keywords : Liver, Antioxidant, Phytochemical, Hepatoprotector Activity

\begin{abstract}
Abstrak
Hati merupakan organ terbesar di dalam tubuh dan merupakan pusat metabolisme dan detoksifikasi senyawa kimia. Sebagai organ pusat, ternyata hati sangat rentan terhadap datangnya berbagai penyakit seperti hepatitis ataupun penyakit lainya. Penyakit hepatitis dapat terjadi karena sistem imunitas tubuh menurun sehingga virus hepatitis dengan leluasa dapat menginfeksi hati atau terbentukanya radikal bebas di dalam hati sehingga menyebabkan peradangan pada hati akibat pengaruh dari pola hidup yang tidak sehat. Konsentrasi dari radikal bebas yang tidak seimbang dengan antioksidan di dalam tubuh dapat menimbulkan stress oksidatif pada tubuh yang dapat menyebabkan kerusakan sel sehingga dapat menimbulkan penyakit degeneratif misalnya penyakit liver. Kerusakan yang disebabkan oleh radikal bebas di dalam tubuh dapat diatasi dengan antioksidan. Berdasarkan hasil penelitian yang telah dilakukan sebelumnya, diketahui bahwa ekstrak kerang ale-ale memiliki aktivitas antioksidan. Tujuan dari penelitian ini adalah untuk untuk mengetahui komponen kimia dari ekstrak kerang ale-ale (Meretrix sp.) dengan melakukan uji fitokimia dan aktivitas hepatoprotektor dari ekstrak kerang ale-ale terhadap kadar SGPT dan SGOT dari kelinci yang diinduksi dengan $\mathrm{CCl}_{4}$. Dari penelitian ini diketahui bahwa hasil pengujian fitokimia menunjukan bahwa senyawa alkaloid terkadung pada ekstrak kerang ale ale. Aktivitas hepatoprotektor dari ekstrak kerang ale-ale (Meretrix sp.) memiliki kemampuan dalam menurunkan kadar SGPT dan SGOT dari serum darah kelinci yang telah diinduksi dengan $\mathrm{CCl}_{4}$.
\end{abstract}

Kata kunci : Hati, Antioksidan, Fitokimia, Aktivitas Hepatoprotektor 
Jurnal Laut Khatulistiwa, Vol. 4. No. 1 (Febuari, 2021), Hal. 50-55.

\section{Pendahuluan}

Hati merupakan organ terbesar di dalam tubuh dan merupakan pusat metabolisme dan detoksifikasi senyawa kimia yang sangat rentan terhadap datangnya berbagai penyakit seperti hepatitis ataupun penyakit lainya (Lukluaningsih, 2014). Penyakit hepatitis yang disebabkan karena virus hepatitis ataupun radikal bebas dapat mengakibatkan infeksi atau peradangan pada organ hati (Viswanath, 2012).

Hepatoprotektor merupakan senyawa yang dapat memberikan perlindungan pada hati dari kerusakan. Salah satu cara untuk mengetahui tingkat kerusakan hati adalah dengan mengukur konsentrasi dari enzim SGPT dan SGOT (Yusuf et al, 2018). Penelitian tentang kerang yang memiliki aktivitas hepatoprotektor sudah di publikasikan. Kerang Tiram Pasifik (Crassostrea gigas) dapat menurunkan serum AST dan serum ALT dari kerusakan organ hati tikus akibat induksi $\mathrm{CCl}_{4}$ pada model akut dan kronis (Shi et al, 2015). Kerang air tawar (Corbicula fluminea) bisa mereduksi serum AST dan serum ALT dan juga menurukan reaksi zat asam thiobarbiturik, hidroksiprolin dan peradangan yang berlebih dari organ hati tikus (Hsu et al, 2010). Beberapa laporan tentang pemberian oral ekstrak kerang kepada tikus juga menurunkan kerusakan organ hati akibat induksi $\mathrm{CCl}_{4}$ dan alkohol (Maekawa et al, 2003; Lin, 2003).

Konsentrasi dari radikal bebas yang tidak seimbang dengan antioksidan di dalam tubuh dapat menimbulkan stress oksidatif pada tubuh. Stress oksidatif tersebut dapat menyebabkan kerusakan sel sehingga dapat menimbulkan penyakit degeneratif misalnya penyakit liver (Sen, 2010). Kerusakan yang disebabkan oleh radikal bebas di dalam tubuh dapat diatasi dengan senyawa antioksidan.

Antioksidan merupakan substansi yang dapat menghambat, mencegah atau menghilangkan kerusakan oksidatif yang disebabkan oleh radikal bebas (Halliwell dan Gutterridge, 2007). Tubuh secara alami memproduksi antioksidan endogen yang mampu mengatasi efek dari radikal bebas, tetapi jika pasokan radikal bebas meningkat atau antioksidan endogen tidak mencukupi untuk melawan radikal bebas tersebut maka dibutuhkannya pasokan antioksidan dari luar (Kalija, 2020). Antioksidan dapat berasal dari bahan alami maupun sintetik. Sumber antioksidan alami telah banyak dilaporkan berasal dari tumbuhan dan hewan. Salah satu hewan yang dapat dijadikan sebagai sumber antioksidan alami adalah kerang ale-ale (Meretrix sp.).

Kerang ale-ale (Meretrix sp.) merupakan hewan bivalvia yang menjadi salah satu komoditas laut unggulan Kalimantan Barat (Suci, 2016). Kerang ale-ale merupakan hewan yang cukup popular di dalam dunia kuliner. Hewan ini sering digunakan sebagai bahan masakan khas yang cukup diminati oleh banyak orang, khususnya para turis yang sering berkunjung ke Ketapang dan Pontianak (Kalija, 2020). Selain sebagai sumber pangan, berdasarkan pengalaman tradisional, masyarakat pesisir ketapang sering menggunakan kerang-kerangan sebagai obat tradisional dalam menyebuhkan penyakit khususnya penyakit liver (hepatitis/kuning).

Hasil penelitian yang telah dilakukan oleh Kalija (2019) dan Nurhamidah (2019) menunjukan bahwa ekstrak kerang ale-ale memiliki aktivitas antioksidan. Berdasarkan pemahaman tersebut, diperoleh suatu pemikiran bahwa dengan memperoleh senyawa bioaktif yang memiliki aktivitas antioksidan dapat memberikan potensi untuk menanggulangi kerusakan oksidatif pada hati.

\section{Metodologi Penelitian \\ 2.1 Waktu dan Lokasi Penelitian}

Alat-alat yang digunakan pada penelitian ini adalah blender, bejana maserasi, gelas kimia, batang pengaduk, timbangan, vakum evaporator, tabung reaksi, rak tabung reaksi, pipet tetes, tabung serum, sentrifuge, spuit, mikropipet, kuvet dan spektrofotometer UVVIS.

Bahan-bahan yang digunakan pada penelitian ini adalah, daging kerang ale-ale, Etanol p.a, pereaksi Dragendroff, Mayer, Wagner, Libermand-Burchand, $\mathrm{FeCl}_{3}, \mathrm{NaOH}$ 10\%, Fitofarmaka (Curcumin), Karbon Tetraklorida, Kit SGPT dan SGOT dan kelinci sebagai hewan uji.

\subsection{Prosedur Kerja \\ 2.2.1 Ekstraksi Sampel}

Daging kerang ale-ale yang telah dicuci bersih ditimbang sebanyak $200 \mathrm{~g}$ dan dihaluskan menggunakan blender. Kemudian 
dimasukkan ke dalam bejana maserasi dan ditambahkan pelarut etanol p.a sebanyak 200 mL dengan perbandingan 1:1 selama $3 \times 24$ jam. Maserasi yang sudah melewati masa perendaman 24 jam akan dilakukan penyaringan terhadap sampel dan dilanjutkan dengan pergantian pelarut baru yang dilakukan sesuai durasi yang telah ditentukan. Setelah proses ekstraksi selesai, dapat diasumsikan bahwa seluruh komponen kimia di dalam sampel telah keluar. Ekstrak cair kemudian dipekatkan menggunakan vakum evaporator dengan suhu yang sudah disesuaikan dengan titik didih pelarut.

\subsubsection{Uji Fitokimia Alkaloid}

Sebanyak 1 mL ekstrak etanol dimasukkan kedalam tiga tabung reaksi dan diberi label Dragendroff, Mayer, dan Wagner. Kemudian ditambahkan peraksi sesuai dengan labelnya. Uji positif ditunjukan dengan munculnya endapan jingga kemerahan, (Dragendroff), endapan putih (Mayer) dan endapan coklat (Wagner) (Harbone, 1987).

\section{Flavonoid}

Sebanyak $2 \mathrm{~mL}$ ekstrak etanol dimasukkan kedalam tabung reaksi dan dimasukan ke dalam air mendidih selama 5 menit dan ditambahkan larutan $\mathrm{NaOH}$ 10\% lalu dikocok dengan kuat. Uji positif ditunjukan dengan terbentuknya warna hijau kekuningan.

\section{Triterpenoid dan Steroid}

Sebanyak $1 \mathrm{~mL}$ ekstrak etanol dimasukan kedalam tabung reaksi, kemudian ditambahkan beberapa tetes peraksi Libermand-Burchand dan 1 tetes $\mathrm{H}_{2} \mathrm{SO}_{4}$ pekat. Uji positif ditandai dengan terbentuknya warna hijau (triterpenoid) dan biru (steroid) (Harbone, 1987).

\section{Saponin}

Sebanyak $2 \mathrm{~mL}$ ekstrak etanol ditambahkan $10 \mathrm{~mL}$ air panas dan dikocok kuat. Uji positif ditandai dengan terbentuknya busa yang tidak hilang selama \pm 30 detik (Harbone, 1987).

\subsubsection{Perlakuan Hewan Uji}

Kelinci sebanyak 14 ekor dengan bobot badan seberat satu sampai $2 \mathrm{~kg}$ dibagi menjadi 5 kelompok. semua kelompok diinduksi dengan $\mathrm{CCl}_{4}$ selama 3 hari. Kemudian 4 kelompok diberikan ekstrak dan satu kelompok dijadikan sebagai kontrol negatif. Dari 4 kelompok, satu kelompok diberikan curcumin sebagai kontrol positif, tiga kelompok diberikan ekstrak etanol kerang aleale dengan konsentrasi ekstrak dibagi menjadi 100; 150 dan 200 ppm untuk SGPT dan 50; 100 dan 150 ppm untuk SGOT. Proses ini dilakukan di Laboratorium Jasa Pengujian, Kalibrasi dan Sertifikasi (LJPKS) Institut Pertanian Bogor.

\subsubsection{Pengukuran Kadar SGPT dan SGOT}

Prinsip pengukuran aktivitas SGPT dan SGOT adalah mengukur laju berkurangnya jumlah NADH menjadi NAD+ pada reaksi yang terjadi antara enzim dan substrat yang dapat diukur pada panjang gelombang $340 \mathrm{~nm}$. Sampel darah kelinci disentrifugasi pada kecepatan 3000 rpm selama 15 menit untuk mendapatkan serumnya dan dilakukan analisis kadar SGPT dan SGOT. Serum darah kelinci sebanyak $100 \mu \mathrm{L}$ dicampur dengan $1000 \mu \mathrm{L}$ reagen, kemudian diukur serapannya dengan menggunakan spektrofotometer UVVIS pada panjang gelombang $340 \mathrm{~nm}$. Pengujian dilakukan di Laboratorium Jasa Pengujian, Kalibrasi dan Sertifikasi (LJPKS) Institut Pertanian Bogor

Pengukuran aktivitas kedua enzim tersebut dilakukan dengan cara yang sama, hanya saja reagen yang digunakan berbeda. Reagen yang digunakan dalam pengukuran SGOT mengandung buffer Tris $\mathrm{pH} 7.8$, Laspartat, 2-oksoglutarat, laktat dehidrogenase, malat dehidrogenase, dan NADH. Pereaksi yang digunakan dalam pengukuran SGPT mengandung buffer Tris, L-alanin, 2oksoglutarat, laktat dehidrogenase, dan NADH (Ramdaniah, 2014).

\section{Hasil dan Pembahasan}

\subsection{Kandungan Fitokimia}

Uji fitokimia merupakan uji pemeriksaan kualitatif yang bertujuan untuk mendeteksi kandungan kimia yang terdapat di dalam sampel. Pengujian ini merupakan pengujian yang sering dilakukan karena pengujian fitokimia merupakan pengujian awal untuk mendeteksi senyawa kimia yang terkandung 
Jurnal Laut Khatulistiwa, Vol. 4. No. 1 (Febuari, 2021), Hal. 50-55.

Tabel 1. Hasil Uji Fitokimia dari Ekstrak Etanol Kerang Ale-Ale (Meretrix sp.)

\begin{tabular}{|c|c|c|}
\hline No & Uji Fitokimia & Hasil \\
\hline 1 & Alkaloid & + \\
\hline 2 & Flavonoid & - \\
\hline 3 & Triterpenoid & - \\
\hline 4 & Steroid & - \\
\hline 5 & Saponin & - \\
\hline
\end{tabular}

berdasarkan terbentuknya sebuah indikator pada saat pengujian berlangsung (Harbone, 1987).

Berdasarkan penelitian yang pernah dilakukan, diketahui bahwa Meretrix sp. memiliki kandungan senyawa metabolit sekunder yang terdiri dari alkaloid, steroid dan saponin (Jakaria, 2013; Apriandi, 2018; Kalija, 2020).

Hasil pengujian menunjukan bahwa ekstrak etanol kerang ale-ale (Meretrix sp.) memiliki senyawa alkaloid yang terkadung pada ekstrak kerang ale-ale. Hal ini disebabkan karena jenis pelarut yang digunakan dalam proses ekstraksi adalah jenis pelarut polar yaitu etanol. Hasil pengujian dapat dilihat pada Tabel 1 .

\subsection{Aktivitas Hepatoprotektor \\ 3.2.1 Kandungan Logam Berat pada Air}

Salah satu cara untuk mengetahui tingkat kerusakan hati adalah dengan mengukur konsentrasi dari enzim SGPT dan SGOT (Yusuf et al, 2018). Serum glutamic pyruvat transminae (SGPT) merupakan enzim aminotransminase yang dapat ditemukan di dalam sel hepatosit dan Serum glutamic oxaloacetic transminase (SGOT) merupakan enzim aminotransminase yang dapat ditemukan di dalam sel hepatosit, sel jantung dan ginjal. SGPT merupakan enzim yang mengkatalis pemindahan gugus amino antara alanin dan asam alfa ketoglutarat (Bastiansyah, 2012). Sedangkan SGOT merupakan enzim yang melakukan reaksi antara asam aspartate dan asam alfa ketoglutamat (Sacher and McPerson, 2013).

Kedua enzim aminotransmiase ini memiliki kadar 5-40 U/L di dalam darah pada keadaan normal. Kadar kedua enzim ini dapat meningkat dari kadar normal jika sel hati mengalami kerusakan (Sacher and McPerson, 2013). Keadaan ini dapat terjadi karena sel hepatosit yang telah rusak akan mengeluarkan seluruh isi selnya ke dalam darah sehingga peningkatan tersebut dapat terjadi dan sering digunakan sebagai indikasi awal dari seberapa parah kerusakan hati yang sedang terjadi (Ramdaniah, 2014). Hasil pengukuran SGPT dan SGOT ekstrak etanol kerang Ale-ale (Meretrix) (U/L) dapat dilihat pada Tabel 2.

Pada penelitian ini, K1, K2 dan K3 merupakan kelompok perlakuan dengan pemberian ekstrak etanol kerang ale-ale (Meretrix sp.) dengan konsentrasi 100 (K1), 150 (K2) dan 200 (K3) ppm (SGPT) dan 50 (K1), 100 (K2) dan 150 (K3) ppm (SOGT). Tabel 2 menunjukan bahwa seluruh kelompok perlakuan yang telah diinduksi dengan $\mathrm{CCl}_{4}$ selama tiga hari menunjukan penurunan setelah diinduksi dengan ekstrak kerang aleale (Meretrix sp.) selama tiga hari selanjutnya. Hasil uji statistik menunjukkan bahwa kelompok perlakuan ada yang menunjukkan tidak berbeda nyata dan ada yang berbeda nyata $(\mathrm{P}<0,01)$. Hal tersebut dapat terjadi karena proses penyembuhan sel-sel hepatosit di organ hati yang disebabkan oleh pengaruh dari ekstrak kerang ale-ale (Meretrix sp.). Hasil pengukuran dapat dilihat pada Tabel 2 dimana kelompok yang memiliki kode huruf yang sama berarti menunjukan tidak berbeda nyata dan kode huruf yang berbeda menunjukan berbeda nyata $(\mathrm{P}<0,01)$. Hasil pengukuran kadar SGPT dan SGOT menunjukkan bahwa kelinci yang diberikan ekstrak kerang ale-ale (Meretrix sp.) menunjukan penurunan. Terlihat pada Tabel 2. Penurunan pada K2 (20,98 U/L dan 30,28 U/L) dan K3 (19,49 U/L dan 28,09 U/L) menunjukan perbedaan yang signifikan terhadap kelompok $\mathrm{CCl}_{4}$.

Terjadinya penurunan kadar enzim SGPT dan SGOT merupakan salah satu indikasi dari kesembuhan sel-sel hati yang mengalami kerusakan yang diakibatkan oleh penginduksian dari $\mathrm{CCl}_{4}$ setelah pemberian ekstrak kerang ale-ale. Hal ini disebabkan 
Jurnal Laut Khatulistiwa, Vol. 4. No. 1 (Febuari, 2021), Hal. 50-55.

Tabel 2. Hasil Pengukuran SGPT dan SGOT Ekstrak Etanol Kerang Ale-ale (Meretrix sp.) (U/L).

\begin{tabular}{ccc}
\hline \multirow{2}{*}{ Perlakuan } & \multicolumn{2}{c}{ Ekstrak Kerang Ale-ale } \\
\cline { 2 - 3 } & SGPT & SGOT \\
\hline CCl $_{4}$ & $23,46 \pm 0,70 \mathrm{~b}$ & $35,34 \pm 0,52 \mathrm{~b}$ \\
Kontrol & $21,19 \pm 0,50 \mathrm{a}$ & $27,36 \pm 0,27 \mathrm{a}$ \\
K1 & $22,88 \pm 1,05 \mathrm{~b}$ & $33,91 \pm 1,69 \mathrm{~b}$ \\
K2 & $20,98 \pm 0,49 \mathrm{a}$ & $30,28 \pm 1,02 \mathrm{c}$ \\
K3 & $19,49 \pm 0,49 \mathrm{c}$ & $28,09 \pm 0,69 \mathrm{a}$ \\
\hline
\end{tabular}

karena pada kerang ale-ale memiliki aktivitas antioksidan. Senyawa antioksidan dapat bertindak sebagai penghambatan dari penyebaran radikal bebas di dalam tubuh. Senyawa aktif tersebut memiliki kemampuan sebagai penangkap (scavenger) dengan cara mendonorkan atom hidrogennya pada radikal bebas (Ramdaniah, 2014).

\section{Kesimpulan}

Kesimpulan dari hasil penelitian yang telah dilakukan adalah pengujian fitokimia dari ekstrak kerang ale-ale (Meretrix sp.) mendeteksi adanya senyawa alkaloid dan aktivitas hepatoprotektor dari ekstrak kerang ale-ale (Meretrix sp.) memiliki kemampuan yang cukup baik dalam menurunkan kadar SGPT dan SGOT dari hati kelinci akibat radikal bebas yang disebabkan oleh penginduksian karbon tetraklorida $\left(\mathrm{CCl}_{4}\right)$. Penurunan terbaik berada pada kelompok perlakuan K3 dengan kadar SGPT 19,49 U/L dan kadar SGOT 28,09 $\mathrm{U} / \mathrm{L}$.

\section{Ucapan Terima Kasih}

Penulis mengucapkan terimakasih kepada orang tua, dosen pembimbing dan penguji skripsi serta teman-teman seperjuangan atas bimbingan dan dukungannya dalam penyelesaian penelitian ini

\section{Daftar Pustaka}

Bastiansyah, E. 2012. Panduan Lengkap Membaca Hasil Tes Kesehatan. Penerbit Plus, Jakarta.

Halliwel B., J. M. C. Gutteridge. 2007. Free Radical In Biology and Medicine. UK: Oxfrod University.

Harbone, J. B. 1987. Metode Fitokimia. Bandung: Institut Teknologi Bandung.
Kalija, T. A. 2019. Komponen Bioaktif dan Aktivitas Antioksidan Ekstrak Kasar Kerang Ale-ale (Meretrix sp.) Segar dan Fermentasi. Skripsi. Pontianak: Universitas Tanjungpura.

Kannan, A., N. Hettiarachychy, dan S. Arayan. 2009. Colonmn and Breast Anti-Cancer Effect of Peptide Hydroliysates Derived From Rice Barn. Journal The Open Bioactive Coumpounds. 2: 17-20.

Luklukaningsih, Z. 2014. Anatomi, Fisiologi dan Fisioterapi. Edisi 1. Yogyakarta: Nuha Medika.

Lin, C. S. 2003. Effects of Fresh Water Extract on Liver Functions in Alcoholic Liver Injury. Journal Nutr-Sci. 1: 26-33.

Maekawa, Y., Y. Nagamura, dan N. Harda. 2003. Protective Effect of Freshwater Calm Extract Supplementation on Carbon Tetrachloride Induced Liver Injury in Mice. Journal Anal. Bio-Sci. 26: 428-434.

Nurhamidah, A. 2019. Aktivitas Antibakteri dan Antioksidan Isolat Bakteri Asam Laktak (BAL) Yang Diisolasi dari Ale-ale dan Cincalok. Skripsi. Pontianak: Universitas Tanjungpura.

Ramdaniah, P. 2014. Uji Efek Hepatoprotektor Ekstrak Etanol Daun Kembang Merak (Caesalpinia pulcherrima L) Dengan Parameter Enzim SGPT dan SGOT Pada Tikus Jantan (Rattus norvegicus) Yang Diinduksi Parasetamol. Skripsi. Makasar: Universitas Islam Negeri Alauddin.

Sacher dan Mc Person. 2011. Tinjauan Klinis Hasil Pemeriksaan Laboratorium. Edisi 11. Jakarta: EGC Penerbit Buku Kedokteran.

Sen S., R. Chakraborty, C., Y. S. R. Sridharl, Reddy, De B. 2010. Free Radical, Antioxidant, Diseases and Phytomedicines: Current Status and Future Prospect. International Journal of 
Jurnal Laut Khatulistiwa, Vol. 4. No. 1 (Febuari, 2021), Hal. 50-55.

Farmatceutical Science Review and

Research. 3(1): 91-100

Suci, I. A. 2016. Sintesis Hidroksiapatit Berbasis Cangkang Kerang Ale-Ale (Meretrix meretrix) dan Pelapisannya Pada Paduan Logam CoCr Mo. Skripsi. Bogor: Institut Pertanian Bogor

Vishwanath, J., G.B. Preetham, K.B. Anil, K. B., dan R.J. Satwik. 2012. A Review on Hepatoprotective Plants. Journal Drug Dev. \& Res. 4(3): 1-8.

Wahyuni, S. 2005. Pengaruh Daun Sambiloto (Andrographis Paniculata, Nees) Terhadap Kadar SGPT dan SGOT Tikus Putih, EJournal UMM. 1(1): 45-53.

Yusuf, M. I., Tee, S. A., Karmila., Jabbar, A. 2018. Efek Hepatoprotektor Ekstrak Terpurifikasi Batang Galing (Cayratia trifolia L.Domin) Pada Tikus Putis Wistar Jantan (Rattus noervegicus). Jurnal Mandala Phar. 